European Journal of Accounting, Auditing and Finance Research

Vol.8, No.3, pp.13-28, March 2020

Published by ECRTD-UK

Print ISSN: 2053-4086(Print), Online ISSN: 2053-4094(Online)

\title{
MICROFINANCE BANKS SERVICES AND SMALL SCALE ENTERPRISES FINANCING IN ABUJA, NIGERIA
}

\author{
Ibitomi Taiwo1 \\ ${ }^{1}$ Air Force Institute of Technology, Kaduna \\ Department of Banking and Finance \\ prof4real4all@yahoo.com
}

\author{
Micah Ezekiel Elton Mike ${ }^{2}$ \\ ${ }^{2}$ Air Force Institute of Technology, Kaduna \\ Department of Accounting \\ eazyfass@gmail.com
}

\begin{abstract}
Microfinance Banks (MFBs) was majorly established in Nigeria to empower and provide financial services to the poor and Small Scale Enterprises (SSES) in the rural and urban areas. Yet the contribution of the SSEs to the Nigerian economy is meagre, this is simply because MFBs is hijack by the money bags in the society. The study therefore, examined the impact of microfinance banks on financing small scale enterprises (SSEs) in Abuja, Nigeria. The specific objectives of the study were to: (i) evaluate the impact of micro loans on SSEs financing in Abuja, Nigeria; (ii) assess the influence of micro savings on SSEs financing in Abuja, Nigeria. The research design used for the study was survey research design. The population of the study comprises of 57 MFBs and 2,794 SSEs in Abuja, Nigeria. A sample of 349 SSEs and 26 MFBs were selected through stratified random sampling techniques. Copies of questionnaires were distributed to the selected sample. The data was analyse through simple percentages and order logit regression. The finding of the study revealed that: (i) an increase in the amount of loan given by microfinance banks increase the growth of small scale enterprises; (ii) an increase in micro savings of small scale enterprises lead to an increase in small scale enterprises financing by microfinance banks. Based on the findings, the study therefore concluded that MFBs impact positively on financing SSEs in Abuja, Nigeria. The study recommends that MFBs should increase the supply of micro loans to SSEs, this will help in a long way to expand their business and create more employment opportunities to the country. The study also stated that more programmes and policies should be put in place that will create an enabling environment for small businesses to operate optimally in Abuja, and other part of Nigeria.
\end{abstract}

KEYWORDS:microfinance banks; small scale enterprises; microloan; micro savings; financing.

\section{INTRODUCTION}

Small Scale Enterprises (SSEs) contribute significantly to the economy of the developed and developing countries of the world by increasing employment generation, revenue earnings and many others. In both developed and emerging economies of the world, SSEs play a critical role in sustainable economic development and also act as a catalyst for economic growth and development (Normah, 2016; Obokoh, 2018). Thus, the need for apt development of the sector cannot be overemphasized as it has the ability to stimulate indigenous entrepreneurship, create more jobs, mobilize raw materials and semi-processed products as inputs for large- scale enterprises, and contributes to Gross Domestics Products (GDP) of many countries (Lawrence, 
European Journal of Accounting, Auditing and Finance Research

Vol.8, No.3, pp.13-28, March 2020

Published by ECRTD-UK

Print ISSN: 2053-4086(Print), Online ISSN: 2053-4094(Online)

James \& Udechukwu, 2016). Despites these contributions, the Financing of Small Scale Enterprises (SSEs) is a major constraints in developing countries majorly among the deposit money banks due to the high risk of non-performing loans from the enterprises. This led to many deposit money banks denying the poor and SSEs in both urban and rural areas in Nigeria access to financial services. In order to bridge this gap, the government of Nigeria established various institutions as well as programmes to enhance the standard of living of people, provide loans to SSEs, and poor people to be self-reliance and turnout more entrepreneurs than job seekers in the country. Some of the programmes established in the past by the government of Nigeria are Directorate of Food, Roads and Rural Infrastructure (DFFRI), Better life /Family Support Programmes, The Family Economic Advanced Programme, Peoples Bank and many others (Ibitomi \& Ijaiya, 2018). All these programmes failed to achieve their objectives due to poor implementation, corruption and host of many other factors. As a result of the failure recorded in the past, government did not relent in their effort to make financial services accessible to the poor and SSEs, thus, the emergence of Microfinance Banks (MFBs) as an alternative credit system for the poor and SSEs in Nigeria came into existence (Obokoh, Monday \& Ojiako, 2016). The MFBs is meant to empower Micro and SMEs in the rural and urban areas through the provision of micro loans and also guide them in the usage of those loans for the growth of their businesses. Central Bank of Nigeria (CBN) (2005) asserted that MFBs was majorly established for the purpose of provision of financial services to the poor and Micro, Small and Medium Scale Enterprises (MSMEs) who are traditionally not served by the conventional financial institutions. MFBs are majorly responsible for assisting MSMEs, the poor and households who have no access to formalized financial institutions in accessing funds (capital) for the growth of their businesses (Duru \& Ogbe, 2013). The loans of MFBs are mostly for selfemployed individuals, household-based vendors who operate small retail shops, street vending, artisan, manufacture and service provision, so that they can be able to grow their businesses in order to reduce unemployment and contributes to the growth of the economy (CBN, 2006). Today, there is comparatively little convincing evidence on ground with respects to the success of MFBs services on financing small businesses because of high cost of making the loans available to businesses (Zinman, 2019). The Abuja, Nigeria has the highest number of microfinance banks in Nigeria due to the presence of high profile people and business in the town and also been the administrative headquarters of Nigeria. This zone comprises of the highest microfinance banks in Nigeria (CBN, 2018).

The study therefore was guided by the following objectives:

i. To examines the impact of micro loans on small scale enterprises financing in Abuja, Nigeria ;

ii. To assess the influence of micro savings on small scale enterprises financing in Abuja, Nigeria ;

The following research questions were raised with a view of achieving the objectives of this study.

What impact does micro loans have on small scale enterprises financing in Abuja, Nigeria? To what extent do micro savings impact on small scale enterprises financing in Abuja, Nigeria? 
European Journal of Accounting, Auditing and Finance Research

Vol.8, No.3, pp.13-28, March 2020

Published by ECRTD-UK

Print ISSN: 2053-4086(Print), Online ISSN: 2053-4094(Online)

To proffer answers to the research questions raised and realized the study objectives, the study seeks to test the following hypotheses which were stated in null form.

Ho1: Micro loans do not have significant impact on SSEs financing in Abuja, Nigeria.

Ho2: Micro savings does not have significantly impact on SSEs financing in Abuja, Nigeria.

This study was necessary because of the recent philosophy of the present government in reducing the rate of unemployment and to finance small businesses in Nigeria. Since Abuja is where the administrative headquarters of Nigeria is located, the study of this nature will allow us to examine the impact of MFBs on SSEs Abuja, Nigeria. There is heavy present of MFBs in Abuja, Nigeria which constituted about 7\% of the total MFBs in Nigeria (57 MFBs out of 1007 MFBs in Nigeria), (CBN, 2018). The scope of this study covers from 2017 to 2019, the reason for the choice of 2017 was due to the year this study started.

\section{LITERATURE REVIEW}

\section{Concept of Microfinance Banks}

Ofoegbu, Akambi and Joseph (2013) described microfinance banks as any financial services that are flexible in structure and processes which are delivered to small scale enterprise as well as low income earners and the poor on a sustainable basis. In Nigeria microfinance banks therefore is seen as poverty reduction strategy that is carried out in providing credit and other financial active and low income households and their businesses (Acha, 2012). The practice of microfinance banks is not new in Nigeria, it has been in existence providing the needed finances through informal microfinance approaches such as self-help groups, credit associations, accumulating credit, savings association and direct borrowing from friends and relations and community banks (CBN 2005; Akpan, 2009; Okpard, 2009).

The distinguishing features of microfinance banks according to Olaifa (2017) are stated below:

i. Simple operations for their activities

ii. Giving of small loans and collections of small savings

iii. Removal of collateral security as a condition for loam advances.

There shall be three (3) categories of MFBs in Nigeria (Revised regulatory and supervisory guidelines for MFBs in Nigeria, 2012).

\section{Category 1: Unit Microfinance Bank}

A Unit Microfinance Bank is authorized to operate in one location. It shall be required to have a minimum paid-up capital of N20 million (twenty million Naira) and is prohibited from having branches and/or cash centres.

\section{Category 2: State Microfinance Bank}

A State Microfinance Bank is authorized to operate in one State or the Federal Capital Territory (FCT). It shall be required to have a minimum paid-up capital of N100 million (one hundred 
European Journal of Accounting, Auditing and Finance Research

Vol.8, No.3, pp.13-28, March 2020

Published by ECRTD-UK

Print ISSN: 2053-4086(Print), Online ISSN: 2053-4094(Online)

million Naira) and is allowed to open branches within the same State or the FCT, subject to prior written approval of the $\mathrm{CBN}$ for each new branch or cash centre.

\section{Category 3: National Microfinance Bank}

A National Microfinance Bank is authorized to operate in more than one State including the FCT. It shall be required to have a minimum paid-up capital of N2 billion (two billion Naira), and is allowed to open branches in all States of the Federation and the FCT, subject to prior written approval of the $\mathrm{CBN}$ for each new branch or cash centre.

In Nigerian concept, microfinance banks are institutions constructed as a company, licensed to carry on the business of providing microfinance services such as micro credit loans, insurance, money transfer services and other non-financial services that are needed by the poor as well as the small-holder or micro enterprises.

Emmanuel and Ikenna (2015) noted that diversification of ownership is encouraged to enhance good cooperate governance of licensed MFBs, hence, microfinance institutions can be established by individuals, groups of individual, churches, community development associations, private corporate entities, missionaries and foreign investors

\section{Microfinance Banks Services}

The term microfinance banks is seen as provision of financial services to low income clients including the self-employed. Financial services generally include savings and loan/credit. In addition to financial intermediation, many microfinance banks provide social intermediation services such as development of self-confidence and training in financial literacy and management capabilities among members. Microfinance banks services were discussed below.

\section{Micro Loans}

Bauchet, Marshall, Starita, Thomas and Yalouris (2011) asserted that the narrative of microcredit as providing small loans to capital constrained micro-entrepreneurs who then earn a high return on the loans to be able to repay a relatively high interest rate, and re-invest in their businesses to grow further, and eventually move out of poverty. The provision of small loans to the poor, usually in cash, although occasionally in kind (Lacalle, Rico \& Duran, 2008). Interest rates vary considerably, but are often between 20 percent and 40 percent per year. Roodman (2011) hinted that as MFBs mature, rigid terms tend to be relaxed, leading to, among other things, lower interest rates. While a number of MFBs charge a flat rate on the full amount borrowed, there is a shift to charge interest on the declining balance. Further, charging a variable interest has become more common, meaning that the rate is not fixed over the loan period but rather fluctuates, based on another interest rate, usually the prime rate.

\section{Micro savings}

Savings mobilization has recently been recognized as a major force in microfinance. In the past, microfinance focused almost exclusively on credit; savings were the "forgotten half" of financial intermediation. The availability of deposit services, sometimes purely stand-alone savings accounts, but often linked to credit, either as a compulsory condition of having a loan, or sometimes part of a combined intervention in which a group saves, and then members are allowed to borrow from their shared savings resource. The types of micro-savings services thus 
European Journal of Accounting, Auditing and Finance Research

Vol.8, No.3, pp.13-28, March 2020

Published by ECRTD-UK

Print ISSN: 2053-4086(Print), Online ISSN: 2053-4094(Online)

vary, are offered by various types of providers, and function both as protection (to ameliorate the impact of shocks) and promotion (to build an asset base) (Hulme, Moore \& Barrientos, 2009).

\section{Concepts of Small Scale Enterprises}

The concept of Small Scale Enterprises (SSEs) is one of the most reviewed topic in management due to the importance attached to it by various scholars and its impact in an economy like ours in the country. Worldwide, SSEs is seen as the engine room of economic growth and development (Suberu, Aremu \& Popoola, 2018). The meaning of SSEs varies from one country to another, institutions to institutions and years to years. Sometimes, in the literature, small scale business, small scale industries and small scale entrepreneurship are majorly used interchangeably to mean SSEs.

Some of the following definitions are given in relations to small scale enterprises. The National Directorate of Employment (1989) defined small scale business to include any business enterprises with capital outlay as low as $\mathrm{N}-5,000$ and number of employees fewer as three persons. It has been seen that this definition lacks merit simply because some of SSEs likes salon hairdresser, shoe maker or Sea Street for instance need capital investment of more than $\mathbb{N} 5,000$ to start up a business as at then, simply because of the cost of acquisitions of working tools like machines, dryers and other accessories. Mohammed (1990) defined small scale enterprises as any business organization in which the total worth of the business is less than $\$ 4000,000.00$ including the fixed assets and the cost of investment projects (excluding land). Ibitayo (1991) defined small scale enterprise as a business organization with a return of not more than $\mathbb{N}$ 750,000 and with employees of not more than 50 full time workers (including investment and working capital). Ekpenyong (1999) defined small scale enterprises as a business that have relatively little capital investment outlay that produces in small quantities as a result of control of a small share of the market and employ not more than fifty workers and the planning and entrepreneurial functions are vested in the hands of the owners. This definition is also faulty simply because it fail to mention the amount required to start up small scale business, as the author defined his omission based on the violability and hairdresser to the capital formation and this makes it imperative to accept the definition.

Watson and Everett (1999) asserted that the most functional definition of SMEs is one given by United Nations Industrial Development Organisation (UNIDO) which states that small scale business should be characterized by the following variables:

i. The business are majorly owned and managed by individual or group and the management is different from the owners.

ii. The business enterprises controls small share of the market and therefore constitutes a little quota in the large size market.

iii. The owners provide the capital for the business enterprises and policy decision with respect to the business enterprises are taken by the owners.

iv. The area of the operation and workers are in the local community for variable patronages and supply. 
European Journal of Accounting, Auditing and Finance Research

Vol.8, No.3, pp.13-28, March 2020

Published by ECRTD-UK

Print ISSN: 2053-4086(Print), Online ISSN: 2053-4094(Online)

There is no generally acceptable definition of small scale enterprise as shown by various studies (Oleka, Naduagwu \& Igwenagu, 2014, Zhiri, 2017; Adeoti, Abadeyan \& Olawale, 2015; Obokoh, Monday \& Ojiaka 2016; Emmanuel \& Ikenna, 2015; Okoh, Ugwumba \& Isitor, 2009).

Anyanwu (2004) opined that the classification of SSEs depends largely on the economics sectors

\section{THEORETICAL REVIEW}

Linear growth theory supported this study.

\section{Linear Growth Theory}

The linear growth theory is propounded by Harrold 1939 and Domar 1946 which is commonly called Harrold Domar growth model. The assumption of the theory stated that for steady growth rate to occur in business, aggregate demand must also grow at the same rate as the economy output capacity grows. The assumptions states that there are two major determinants to the rate of growth of a business. The first is the capital investments and its output called the capitaloutput ratio, this assumptions stated that the more capital is invested in business the higher the output will be and this will help in contributing to the growth of the economy. The second assumption is the relationship between savings and national income called savings ratio, this states that the higher the savings of the business the more the economy will grow. Therefore, the growth of any business is a function of financing i.e. SSEF = F (MFBs, GEE) where SSEF is Small Scale Enterprise Financing, $\mathrm{f}$ is function, MFBs is Micro Finance Banks, GEE is Government Enabling Environment.

This implies that for any business to grow, there is need for heavy investment and for heavy investment to take place, there is need for corresponding of loans and savings to be provided by an institutions such as microfinance banks, this will enable more investment by small businesses to gain more and expand their businesses. Despites the various efforts made to lend finances to small businesses, the rate of their improvement in the business is hindered by the country and the global economic performance. As the national economic performance grows the small scale businesses also perform well simply because more business opportunities will be open. This theory therefore believes that the activities perform by the microfinance banks in carrying out their core mandates through credit provision, savings mobilization, insurance training etc. serves as a turning ground and tools for increasing the productive capacity of small businesses, therefore the development of MFBs served as financial intermediaries that contributes to economic growth of rural areas by channeling savings to high productive activities and reduction of risks that may endangered their productive capacity. For growth to occur in SSEs, there must be heavy investment in small scale enterprises and for heavy investment to take place. It is the functions of the MFBs since the DMBs are mostly reluctant of financing SSEs due to the risk attached to it.

\section{Empirical Review}

Pie-Wen, Zariyawati, Diana-Rose and Annuar (2016) studied the impact of microfinance banks facilities on the performance of small and medium enterprises in Malaysia. The study used survey research design. The method of data collection was through primary data with the use of 
European Journal of Accounting, Auditing and Finance Research

Vol.8, No.3, pp.13-28, March 2020

Published by ECRTD-UK

Print ISSN: 2053-4086(Print), Online ISSN: 2053-4094(Online)

questionnaire distribution. The sample size used for the study was 125 SMEs. The independent variables used for the study were business income, total loan granted, loan tenure, educational level, and business training. Logic regression was used for the analysis of the data. The findings of the study revealed that business income has significant impact on microfinance banks loan, total loan granted to SMEs is based on the savings of the business, educational level of the business owners impact significantly on microfinance banks services, loan tenure impacts more on the owners business and business training helps to increase the knowledge of the owners on their businesses. The study concluded based on the findings that microfinance banks impacts positively on SMEs in Malaysia.

Abraham, Sakwa and Aloys (2014) investigated the relationship between small scale enterprises performance and access to microfinance banks credit in Mount Elgon constituency Kenya. The study adopted a descriptive survey design using a primary data collection. The population for the study was 1200 and the sample size used was 120 SSEs which were randomly selected. The method of data analysis was descriptive and inferential statistics, the inferential statistics used were Chi-square and t-tests. The results of the data revealed that there was a significant positive relationship between performance of the business in terms of increase in average monthly profit, monthly business savings, number of employees and access to funds by SSEs. It also reveals that the age of the business, business ownership, having other branches and number of employees significantly affected access to credit in the SSEs.

Awuah and Addaney (2016) examined the interactions between Microfinance banks and SMES in Sunyani municipality of Ghana. Primary data was used with a sample size of 150 SMES. The study found that the main challenges faced by SME in Ghana include short duration of loan payment, huge interest rates and requests for collateral among others. The study also established that the effect of MFIS on SMES is positive.

Musomandera, Jaya and Anthony (2015) studied microfinance banks and business growth of SMEs in Rwanda. The study employed both Primary and secondary data. The population of the study was 884 and sample size of 275 . The method of data analysis was regression analysis. The result of the analysis revealed that MFBs provides many different services to women SMEs in Kicukro such as loan, advice on investment savings and training on business. MFBs also help in the support of different sectors ranging from agricultural sector, trading sector, crafts, agro processing, services, constructions and manufacturing among others.

Zhiri (2017) researched on impact of microfinance banks services on performance of SMEs in Zaria metropolis. Cross sectional and descriptive research designed was used. The sample size for the study was 300 SMEs operating in Zaria metropolis using stratified random sampling. The method of data analysis was regression analysis. The analysis of the data reveals that microfinance banks services have significant impact on the level of entrepreneurship activities of SMEs in Zaria metropolis and also the presence of microfinance institutions is positively related to SMEs performance in Zaria. 
European Journal of Accounting, Auditing and Finance Research

Vol.8, No.3, pp.13-28, March 2020

Published by ECRTD-UK

Print ISSN: 2053-4086(Print), Online ISSN: 2053-4094(Online)

Taiwo, Onasanya, Agwu and Benson (2016) examined the role of microfinance banks on financing small businesses in Nigeria. Descriptive research design was employed for the study. Primary data was used. The sample size for the study was 150 small businesses across Lagos State using stratified random sampling. The method of data analysis was descriptive and inferential statistics. The analysis of the result revealed that the recapitalization of MFBS has helped in the growth and expansion of small business finance in Lagos. As a result microfinance institutions helped in financing small businesses in Lagos state.

Agor, Essien and Ndiyo (2016) studied the impact of microfinance banks on financing small scale businesses in Calabar metropolis in Cross Rivers State. The research was descriptive in nature and the design used was survey method. The method of data used was primary data through questionnaires. The sample size used was 60 small scale business enterprise and 40 microfinance banks staff, simple random sampling was used in the selection. The method of data analysis was through simple percentages. The results of the data analysis revealed that microfinance banks have positive significant impact on the growth of small and medium business enterprises and also that there is an increase in the awareness of the activities of microfinance banks which have positive impact on the establishment of SSEs in Calabar.

Obokoh, Monday and Ojiako (2016) studied microfinance banks and small and medium sized enterprises access to finance. The Nigerian experience. The area of the study was in the Niger Delta area which covered the nine states. Akwa Ibom, Bayalsa, Delta and Rivers state were used for the study. Data were collected through primary data, the population of the studies was 800 SMEs and a sample size of 300 SMEs was used for the study. Stratified random sampling techniques was used in the selection of the respondents. The method of data analysis was through frequency, percentage and multiple regression analysis. The result of the findings revealed that there are positive contribution of microfinance banks ending to the development of SMEs in Niger- Delta region. Despites of the contribution the findings also revealed that some factors still affect the success of MFBs lending which include cumbersome process, poorly packed business plans and perceived high cost of credit still limiting the access of indigenous SMEs to credit.

Odetayo (2016) studied empirical analysis of the challenges of microfinance banks in financing small scale enterprises in Nigeria. The study area was in Osun state. Descriptive survey research design was adopted for this study. The population of the study comprises of all the MFBs and small scale enterprises in Osun state. The sample size for the study was 90 microfinance banks staff selected from 30 microfinance banks and 450 small scale enterprises were sampled using purposive random sampling. The method of data analysis was through descriptive statistics. The analysis of the results revealed that, the challenges facing microfinance banks in financing small scale enterprises in Nigeria are payment of loans, deviation from loan agreement, diversion of the loan granted, non-compliance with advice and non-repayment of loans granted.

Adeoti , Gbadeyan and Olawale (2015) investigated the impact of microfinance banks credit on the survival of small and medium scale enterprises in Irepodun Local Government Area (L.G.A) of Kwara State, Nigeria. Primary data was used for this study. The population of the study were the two structural MFBs in Irepodun L.G.A which was also used as the sample size for MFBs, 
European Journal of Accounting, Auditing and Finance Research

Vol.8, No.3, pp.13-28, March 2020

Published by ECRTD-UK

Print ISSN: 2053-4086(Print), Online ISSN: 2053-4094(Online)

the sample size for the SMEs was 320 which were selected from the customers of the MFBs. The method of data analysis was ANOVA. The result of the findings revealed that microfinance banks contribute significantly to the survival of SMEs in the study area.

Oleka, Maduagwu and Igwenagu (2014) investigated the impact of microfinance banks on the performance of small and medium scale enterprises in Nigeria. The studies covers the period of 2003 - 2013 (ten years). The method of data collection was primary data and secondary data through the use of questionnaires and annual report of CBN on SMEs. The sample size for the study was 300 SMEs which were selected through simple random sampling. The method of data analysis was through regression analysis. The results of the study revealed that access to microfinance banks significant enhanced the growth of SMEs in Nigeria and also that business size, business age, business location, loan size, loan maturity are found to have positive effect on SMEs growth.

Nwele, Ogbonna, and Uduimo (2014) studied the impact of microfinance banks' lending on economic growth of third world nations. Study of Nigeria. Primary and secondary data were used for data collection. The analysis of the data was done through programme designs, numerical structure response in implementation and performance model. The results of the findings revealed that microfinance loans have not gone deep enough to ensure a clean break from community and commercial banking practices.

Ashamu (2014) examined the impact of microfinance banks on financing small scale business in Nigeria. The study was carried out in Lagos State which was descriptive in nature. The research design used was survey methods. Primary data was used as a means of data collection. The sample size for the study was 120 small scale enterprises in Lagos state. Purposive sampling technique was used. Descriptive statistics was used as a method of data analysis using sample percentages and chi-square. The findings of the study revealed that MFBs do not impact on SSEs and this resulted in the enormous challenges facing the MFBs in Nigeria.

Yusuf, Amao and Olawale (2014) examined the effects of microfinance banks credit on small scale enterprises in Osun state Nigeria. The area for this study was Irewole local government of Osun state. The study used primary data for sources of data collection. The population of the study was 77,309, stratified and systematic random sampling was used in the selection of the sample size of 120 small scale entrepreneur. Ordinary Least Square (OLS) regression method was used for the method of data analysis. The result of the data revealed that loan repayment period, family size and years in business were the key determinants of business turnover and that the volume of credit available to respondents are affected by repayment period, numbers of sources and interest of loan.

\section{METHODOLOGY}

The model used for this study was formulated from the theory of linear growth theory which this study was anchored upon, the theory stated that Small Scale Enterprises Financing $(\mathrm{SSEF})=\mathrm{f}$ (Microfinance Banks). The model for the study was formulated below. 
Vol.8, No.3, pp.13-28, March 2020

Published by ECRTD-UK

Print ISSN: 2053-4086(Print), Online ISSN: 2053-4094(Online)

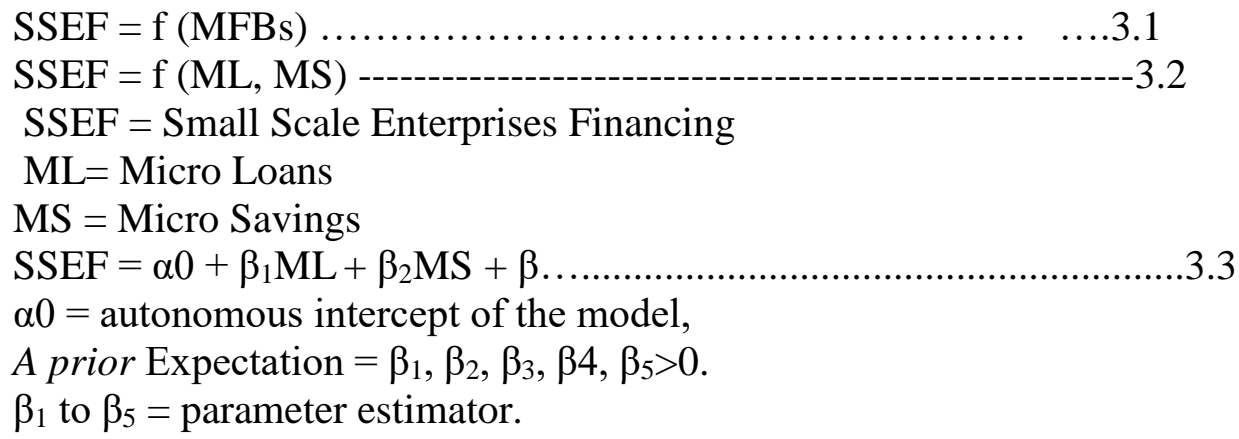

Both descriptive and inferential statistical techniques were used to analyse the data obtained via self-administered questionnaires. Percentages and frequencies were used for descriptive statistical analysis. However, ordered logit regression analysis was employed for inferential statistical analysis because the variables are ranked in nature and the data are on nominal scale of measurement. The scale adopted is both open for demographic data and closed scale for general data. In order to estimate the order logit regression model, E-views econometrics and statistical package was used. The procedure involved specifying the dependent and independent variables; in this case, Micro Loans and Micro Savings was used as the independent variables and small scale enterprises financing was used as the dependent variable. The programs were run and from the output, the values of the constant, $\alpha$ (slope), coefficient of regression, $\beta$ and the error term, $\varepsilon$ are obtained. In addition, the output showed the t-statistic and p-values for the coefficients which results in either rejecting or failure to reject the hypothesis at a specified level of significance. The p-value is the probability of getting a result that is at least as extreme as the critical value. The null hypothesis is rejected if the p-value is less than or equal to the critical value. The output will show the coefficient of determination $\left(r^{2}\right)$, which measures the proportion of the dependent variable that is explained by the regression model.

The research design used for this study was survey research method. The choice of the method was due to the usage of primary sources of data collection through questionnaire and oral interview. The population for this study is 2794 registered small scale enterprises domicile in Abuja (SMEDAN, 2018). The sample size selected for the study was 349 small scale enterprises in Abuja, Nigeria using Yamane (1967) statistical formulae for determination of sample size was used. The sample size was 394 which were selected from artisans, services, manufacturing and trading businesses in Abuja, Nigeria. The method of sampling techniques was stratified sampling for selection of SSEs, the reason for the choice of stratified sampling was due to the different categories of small scale enterprises in Abuja, Nigeria. 
European Journal of Accounting, Auditing and Finance Research

Vol.8, No.3, pp.13-28, March 2020

Published by ECRTD-UK

Print ISSN: 2053-4086(Print), Online ISSN: 2053-4094(Online)

\section{DATA PRESENTATION, ANALYSIS AND DISCUSSION OF FINDINGS}

The descriptive statistics shows the bio-data of the sampled respondents, four hundred and fourteen (414) copies of questionnaire were administered and four hundred and (424) were fully filled and returned which was used for the analysis of this study.

\section{Regression Analysis}

Table 4. 1 presents the ordered logit regression result for the investigation of the impact of MFBs on small scale enterprises financing, ordered logit regression was estimated with small scale financing as the dependent variable and Micro Loan (ML), Micro Savings (MS) as the independent variables. The result shows that all the independent variables are positively related to small scale financing. This means, the better the implementation of these variables, the more likelihood of increase in small scale financing in Abuja, Nigeria.

More so, the result indicates that all the independent variables (ML, MS) are statistically significant at $5 \%$ level of significance. This is shown by the standard error of the marginal effects of the variables 2.9801 and 3.2699. Coefficient (marginal effect) of a variable is said to be significant if the standard error is less than half of the value of the coefficient.

The fitness statistic used in the model is the Log Ratio (LR) chi-square statistics reported along with the marginal effect estimates in Table 4.1. A model is considered to have a good fit when the P-value of the LR statistics is less than the traditional levels (10\%, 5\% and 1\%) of significance used in social and management sciences. Otherwise the fitness of the model is said to be bad. The Log Ratio statistics of the ordered logit regression models presented in Table 4.1 is 49.73 with P-value 0.0033 . This shows that all the models have a good fit and their results are valid and plausible for tenable policy inferences.

Table 4.1: Ordered Logit Estimates for Small Scale Enterprises Financing

\begin{tabular}{|l|l|l|l|l|}
\hline Variables & $\begin{array}{l}\text { Marginal effect } \\
(\mathrm{dy} / \mathrm{dx})\end{array}$ & Std Error & Z-stat & Prob \\
\cline { 1 - 3 } Micro-Loans & 2.9801 & 41.544 & 0.0717 & $0.0014 *$ \\
\hline Micro-Savings & 3.2699 & 0.4154 & 7.8716 & $0.0000^{* * *}$ \\
\cline { 1 - 2 } LR-chi2 & 49.73 & & & \\
\cline { 1 - 2 } Prob (chi2) & 0.0033 & & \\
\hline
\end{tabular}

Source: Field Survey (2019)

Notes: $*, * *$ and $* * *$ denotes statistically significant at $1 \%, 5 \%$ and $10 \%$ significance level respectively.

\section{DISCUSSION OF FINDINGS}

From the analysis carried out, it was empirically established that micro finance banks services has an impact on small scale enterprises financing. This implies that with a unit change in the 
European Journal of Accounting, Auditing and Finance Research

Vol.8, No.3, pp.13-28, March 2020

Published by ECRTD-UK

Print ISSN: 2053-4086(Print), Online ISSN: 2053-4094(Online)

microfinance services (micro loans and micro savings) there is likelihood small scale enterprises financing will increase in Abuja, Nigeria.

However, for detailed analysis it is found that hypotheses $\mathrm{H}_{01}$ and $\mathrm{H}_{02}$ which was the dimensions of micro finance services, namely micro-loans and micro-savings were positive and significantly related to small scale enterprises financing/development. This implies that increase in the amount of loan given is expected to help the small businesses to expand. This result meets our apriori expectation and led to rejection of the null $\left(\mathrm{Ho}_{1}\right)$ hypothesis. An increase in micro savings of the small scale enterprises will lead to increase in small scale enterprises financing. This result meets our apriori expectation and therefore led to the rejection of the null $\left(\mathrm{HO}_{2}\right)$ hypothesis. The result is in consonant with the study of Kisaka and Mwewa (2014); Leah and Willy (2017); Musomandera, Jaya and Anthony (2015); Kibet, Kenneth \& Omwono (2015); Dinah and Benjamin (2015); Quansah, Amaukwah and Aikins (2012). Their findings revealed that significant number of the SSEs benefited from the MFBs loans and savings (i.e. the amount of money collected from the MFBs contributed positively in promoting their businesses and market shares). The implication of this findings is that the more microfinance banks give out micro loans to small scale enterprises the more their businesses grow, that is more loans from microfinance banks to SSEs help the business to carry out more activities for the development of their businesses and at the long run help in reducing unemployment rate in at the country and at large contribute to the economic development of the country. The implication of savings revealed that as SSEs savings increases with the microfinance banks the more the banks gives loans to their business and the more the banks attend to them in terms of financing their businesses.

Finally, the findings from the study are in tandem with linear growth theory which argued that for any business to grow, there is need for heavy investment and for heavy investment to take place, there is need for corresponding of loans and savings to be provided by an institutions such as microfinance banks, this will enable more investment by small businesses to gain more and expand their businesses. Based on the findings of this study, the study therefore concludes that MFBs in ABUJA, Nigeria impacted positively on financing small scale enterprises.

\section{CONCLUSION AND RECOMMENDATIONS}

\section{Conclusion}

This study empirically investigated the impact of Microfinance banks on small scale enterprises financing in Abuja, Nigeria. A significant relationship has been established between microfinance banks and small scale enterprises financing/performance. The study confirms the positive contributions of microfinance banks (micro-loans and micro-savings) towards promoting small scale enterprises market share, production efficiencies and competitiveness. Although microfinance banks in Nigeria are faced with insufficient funds which militates against their efforts to grant sufficient loans to small scale enterprises, yet their tendencies to augment the financial needs of small scale enterprises is considerable acknowledged as shown from the result of this study. Based on the findings, the study therefore concludes that the growth/expansion in SSEs is due to changes in micro loans and micro savings. 
European Journal of Accounting, Auditing and Finance Research

Vol.8, No.3, pp.13-28, March 2020

Published by ECRTD-UK

Print ISSN: 2053-4086(Print), Online ISSN: 2053-4094(Online)

\section{Recommendations}

The following recommendations were made in line with the findings and conclusion of the study:

1. Microfinance banks should persist improvement on their supply of micro-loan to SSEs in other to enhance more business expansion and the capital base/profit of both small scale enterprises and the microfinance banks. Policy makers such as Central Bank of Nigeria, Financial Reporting Council of Nigeria should support local savings institutions such as microfinance banks, that have evolved to meet local financial needs, and whose structure is easily understood in most developing countries.

2. The microfinance banks should help in encouraging the SSEs to save as micro-savings will help SSEs acts as a buffer in terms of shocks which could be economic, environmental, or any disaster and also help microfinance banks to lend more to SSEs.

3. Microfinance banks should help in monitoring SSEs for proper use of their resources for business expansion, more techniques should be given to them on how to grow their business in terms of opportunities within their environment. As this will enhance a good relationship of their businesses to microfinance banks and also for proper funding of their businesses. Policies and programmes to influence the establishment of more micro finance banks in both rural and urban communities should be encouraged by government. This will enhance access to credit, encourage banking/savings habits among the rural and urban dwellers, and ensure even growth and development of small businesses in Nigeria

\section{REFERENCES}

Abraham, K. K., Sakwa. M., \& Aloys, N.K. (2014). The relationship between small scale enterprises performance and access to credit from microfinance institutions in Mount Elgon constituency Kenya. International Journal of Academic Research in Business and Social Science, 4(9), 507-517.

Abdel, H.A., Abdimajid, O.A., \& Ali, Y.S.A. (2013). The accessibility of microfinance banks for small businesses in Mogadishu Somalia. International Journal of Humanities and Social Science, 3(11), 172-180.

Acha, I. A. (2012). Microfinance banks in Nigeria: problems and prospects. Journal of finance and accounting, 1(5) 106-111

Adeyemi, K. S. (2008). Institutional reforms for efficient microfinance operations in Nigeria. Central bank of Nigeria. Bulletin, 32 (1), 26-34

Akpan, J. (2009). Fundamentals of finance . $\left(3^{\text {rd }}\right)$ edition, Uyo; Abaam publishing co. 22-28

Albert, N.W., \& Bwisa, M.H. (2013). Effects of micro finance lending on business performance; a survey of microfinance and small enterprises in Kitale Municipality, Kenya. International Journal of Academic Research in Business and Social Sciences, 3 (7), 56 66.

Anyanwu, C. M. (2004). Microfinance institutions in Nigeria. Policy practice and potentials being a paper presented at G24 workshop constraints to growth in sub-Sahara Africa Pretoria, South Africa, Nov. 29 - 30, 2004.

Asor, A.E., Essien, E.M., \& Ndiyo, N. (2016). The impact of micro financials banks on small scale businesses in Cross River State; a case study of Calabar metropolis. International Journal of Innovative Finance and Economics Research, 4(1), 25-31. 
European Journal of Accounting, Auditing and Finance Research

Vol.8, No.3, pp.13-28, March 2020

Published by ECRTD-UK

Print ISSN: 2053-4086(Print), Online ISSN: 2053-4094(Online)

Awuah, B.S., \& Addaney, M. (2016). The interaction between micro finance institutions and Small and Medium Scales Enterprises in the Sumyani Municipality of Ghana. Asian Development Policy Review, 4(2), 57-64.

Bauchet, J., Marshall, C., Starita, L., Thomas, J., \& Yalouris, A. (2011). Latest findings from randomized evaluations of microfinance. CGAP Access to Finance Forum, Report No 2.

Central Bank of Nigeria (2018). Annual Report and Statement of Accounts. Central Bank of Nigeria, Abuja.

Central Bank of Nigeria (20006). Statistical bulletins for annual reports on microfinance banks

Central Bank of Nigeria (2005). Microfinance policy regulatory and supervisory framework for Nigeria. Abuja CBN.

Dinah, K.A., \& Benjamin, B.G. (2015). Determining the effect of Micro Finance on Small Scale Enterprises; the case of Holive Municipality of Ghana. Research Journal of Finance and Accounting. 6(22), 60-67

Duru, I. U., \& Ogbe, A.A. (2013). Relationship between microfinance banks and financing of small scale enterprises in Kogi State, Nigeria. International Journal of Economic Development, Research and Investment. 4(3), $71-81$.

E k pe n y o n g, D. B., Nyon g, M. O. (1992). Small and medium-scale enterprises in Nigeria: their characteristics, problems and sources of finance. African Economic Research Consortium. Zakuna Printers Ltd, Nairobi, Kenya.

Ibitomi \& Ijaiya (2018, December 4). Impact of microfinance on small and medium sized enterprises in Nigeria proceedings of the $7^{\text {th }}$ international conference on innovation and management (pp. 4-5), Wuhan, China

Ijaiya, M.A.(2011). Informal micro finance and economic activities of the rural dwellers in Kwara South Senatorial District of Nigeria. International Journal of Business and Social Science, 2(15), 136-146.

Kabeert, N. (2001). Conflicts over credit: re-evaluating the empowerment potential of loans to women in rural Bangladesh, conceptualising and evaluating empowerment. World Development. 29(1): 63-84

Madole, H. (2013). Impact of microfinance credit on the performance of SMEs in Tanzania

Musomandera. L., Jaya, S., \& Anthony, L. (2015). Micro finance bank and business growth of women small and medium enterprises in Rwanda. (A case of selected women small and medium enterprises in Kicukiro district). European journal of accounting, auditing and finance research, 3(11), 26-39.

Normah, M.A. (2016, September 4). SMES: building block for economic growth, paper presented at the National Statistics Conference., (pp. 1 - 13) Kuala Lumpuer, Malysia.

Nwakwo, O. (2008). Micro credit finance banks and poverty alleviation in Nigeria: challenges and prospects. Journal Business Administration and Management, 3(1), 41 - 46.

Nwele, J. O., Ogbonna, I.C., \& Udiumo, A.A. (2014). Impact of micro finance lending on economic growth of third world nations: study of Nigeria. International Journal of Business Economies and Management, 1(8), 201-215.

Obokoh, L.O. (2018). Small and Medium Sized Enterprises development under trade liberalization: a survey of Nigerian experience. International Journal of Business and Management, 3(12), 92 - 101.

Obokoh , L.O., Monday, J.U., \& Ojiako, U. (2016). Microfinance banks and small and medium 
European Journal of Accounting, Auditing and Finance Research

Vol.8, No.3, pp.13-28, March 2020

Published by ECRTD-UK

Print ISSN: 2053-4086(Print), Online ISSN: 2053-4094(Online)

sized enterprises access to finance. The Nigerian experience. Journals of Banks and Banks System. 11(4), 111-121.

Odetayo, T.A. (2016). Empirical analysis of challenges of microfinance banks in financing small scale enterprises in Nigeria. Account and Financial Management Journal. 1(5), 301 307.

Ofoegbu, E.O, Akaube, P.A., \& Joseph, A.T. (2013). Effect of contextual factor on the performance of SMES in Nigeria. A case study of chorin metropolis. Management and Applied Economics Journals, 3 (1), 95-114.

Okoh, R.N., Ugwumba, C.O.A., \& Isitor, S.U. (2009). Microfinance for small - scale enterprises development in Anambra state, Nigeria. A gender analysis. Nigerian Journal of research and production, 15 (2), $1-15$.

Okpara, G.C. (2009). A synthesis of the critical factors affecting performance of the Nigeria banking system. European Journal of economics, Finance and administrative sciences, $17,34-44$.

Olaitan, M.A. (2017). Finance of small and medium scale enterprises in Nigeria. Journal of international farm management, 3(2).

Oleka, C.D., Maduagwu, N.S., \& Igwenagu, M.C. (2014). Analysis of the impact of micro Finance Banks on the performance of small and medium scale enterprises in Nigeria. International Journal of management and social sciences, 1(2), 45 - 63.

Quansah, P., Amankwah, E., \& Aikins, E. (2012). Influence of Micro Finance and Small Load Centre (MASLOC) on the development of small scale enterprises in the municipality, Ghana. European Journal of Business Management, 4(1), 1-10.

Suberu, O.J., Aremu, O.S., \& Popoola, E.G. (2011). The impact of micro finance banks on the development of small scale enterprises in Nigeria. Journal of research in international business management,1(8), 251-257.

Sriram, V., \& Mesha, T. (2010). Stimulating entrepreneurship in Africa. World Journal of Entrepreneurship Management and Sustainable Development, 6(4), 257-272.

Taiwo, J.N., Onasanya, A.Y., Agwu, M.E., \& Benson, K.N. (2016). The roles of microfinance banks in financing small businesses. Journal of Internet Banking and Commence, 21 (1), $1-20$.

Tombo, F., Kurokawa, K., \& William, T. (2008). Donor support to private sector development in sub - Sahara Africa; understanding the Japanese oval programme. Jica Odi working paper London and JBIC.

United Nation Economic Commission for Africa (2008). SMEs actors for sustainable development in North Africa office of North Africa.

Varkata M. (2004). greening small and medium sized enterprises. Evaluating environmental policy in vietnami. International Journal of Economics, 2(8), 112 - 122.

Waithanji, S.W. (2011). Effect of microfinance credit on the financial performance of SMES in Kuambu country, Kenya. Journal of business and entrepreneur, 4(2), 234-346.

Wang, X. (2013). The impact of microfinance banks on the development of small and medium enterprises; the case of Taizhour, China. Journals of entrepreneurship development, 1-24.

White, S., \& Juan, C. (2002). Enabling small enterprise through a better business environment. Donor experiences in supporting reforms in the business environment. Committee of Donor ageners for small enterprise development, working group on enabling 
European Journal of Accounting, Auditing and Finance Research

Vol.8, No.3, pp.13-28, March 2020

Published by ECRTD-UK

Print ISSN: 2053-4086(Print), Online ISSN: 2053-4094(Online)

environment, London. Washington D C

Yahaya, K.A., Osemene, O.F., \& Abdulraheem, A. (2011). Effectiveness of micro finance banks in alleviating poverty in Kwara State Nigeria. Global Journal of Management and Business Research, 11(4), 13-19.

Yusuf, S. A., Amao, J.O., \& Olawale, O. T. (2014). Effect of micro credit on small scale enterprises in Osun State, Nigeria. American International Journal of Contemporary Research, 4(6), 190-200.

Zhiri, D.D. (2017). Impact of micro finance banks services on performance of small and medium scale enterprises in Zaria metropolis. International Journal of Scientific Research in Social Sciences and Management Studies, 2(1), 49-64. 